\title{
A Study on the Problems and Countermeasures in the Design of Russian
}

\section{Multimedia Teaching}

\author{
Xueping Zhang ${ }^{1, a}$ \\ ${ }^{1}$ Jilin Agricultural University, Changchun City, Jilin Province, China, 130018 \\ a email:
}

Keyword: Constructivist Learning Theory, Instructional Design, Russian Teaching, Multimedia Teaching

\begin{abstract}
With the rapid development of modern computer technology, the multimedia teaching in colleges and universities is becoming more and more popular. Restricted by the traditional teaching concept, teachers' computer operation level, the multimedia production technology and other factors, there are still many problems in the design of Russian multimedia teaching design. Based on the author's teaching experience, this paper first analyzed the problems in Russian multimedia teaching, then put forward the countermeasures based on the constructivist learning theory to improve the design of Russian multimedia teaching. This paper analyzed the problems and Countermeasures of the current Russian multimedia teaching, which has certain help to further improve the quality of Russian teaching.
\end{abstract}

\section{Introduction}

Constructivism learning theory emphasizes that students are the main body of knowledge and active constructors of knowledge meaning. The role of teachers transform from the communicator of knowledge to the helper and promoter of active construction. Only the way of cooperative communication and the actual situation is conducive to learners' knowledge construction. It is generally believed that the rise of constructivism is closely related to the gradual popularization of multimedia and network technology. It is the multimedia and the network technology resources that provides the powerful material support for the ideal learning environment which is advocated by the constructivism. At the same time, constructivism has become an important theoretical basis of multimedia teaching. During the development of Russian multimedia teaching, there are some problems that should be paid attention.

\section{Problems in Russian Multimedia Teaching}

There is insufficiency in the design of learning environment. Constructivism holds that learning activities should be carried out in a certain situation, and the essence of learning is to use learning scenarios, to achieve the active construction of the knowledge meaning. Situation, cooperation, communication and meaning construction are the four main factors of constructivist learning environment. In other words, constructivism, in particular, emphasizes the creation of real situations, and it is a necessary premise of the construction of meaning and an important part of teaching design. There are two opposite tendencies in the current Russian multimedia teaching design. First, limited by the hardware equipment or teaching place of colleges and universities, the 
use of multimedia teaching is the teacher's own production, and the courseware making is relatively simple and rough. The courseware content just copy the past structured lesson plans to the screen, adding pictures and videos downloaded from the Internet. Teaching explanation is still based on language knowledge to explain, and do not pay attention to create a positive learning environment for students. Second, teachers blindly adhere to the multimedia technology, use a large number of pictures, sound, video and other visual information in the multimedia teaching to stimulate students' sense of sight and hearing. Although this approach is able to improve the learning interest and mobilize a variety of senses to obtain relevant information, the corresponding teaching will also increase the classroom teaching density. In the classroom, teachers' attention is mostly focused on the courseware, while students are staring at the screen copy notes, which inhibited the development of students' thinking and speaking ability to a certain extent. Cramming method of teaching system became a "indoctrination machine", and teacher became a screening and commentator, with no interaction between teachers and students.

There is insufficiency in the design of autonomous learning strategies. In view of learning, constructivism holds that learning is not a passive process, but a process of active construction. Through the interaction between the learner and the environment, the new information is re-recognized and constructed, so as to obtain the understanding of the meaning of knowledge. That is to say, before the study course, the student's mind is not a blank. Through the daily life and their own practice, students have formed their own views on the various phenomena in the objective world, so a large number of simple concepts or pre scientific concepts have been constructed. These former concepts not only guide or determine student's perception process, but also affect the behavior and learning process of the students to solve the problem.

It can be seen that the core of constructivism is the learner's self construction, which requires learners should have a high degree of learning initiative, enthusiasm. How to design and develop autonomous learning strategies in Russian multimedia teaching has not been valued, which is performed in two aspects: On the one hand, the awareness for the role of autonomous learning strategies in multimedia teaching is insufficient. It one-sided views that multimedia is all powerful, if the class does not use the multimedia teaching, it will be a failure. Mastering the advanced multimedia technology can activate the classroom atmosphere, enhance student interest in learning, and improve teaching effect, which does not conform to the requirements of student centered teaching design, as for how to design active learning strategies and how to effectively promote learner autonomy has not been paid enough attention. On the other hand, the relationship between teaching means and purpose is confused. Similar with the traditional teaching of chalk, blackboard, multimedia technology is also a teaching mean, but the media technology can be more conducive to providing real learning situation and rich information resources, so as to promote the learners' knowledge construction. But in many teaching practice, multimedia has become the goal of teaching, and dominated the classroom. Thus, in a lot of lesson plans, teachers add a lot of pictures, animation and video materials, courseware appearance is gorgeous, but ignored the teaching content, so that students can not focus on the teaching content of multimedia materials.

\section{Russian Multimedia Teaching Design under the Guidance of Constructivism Theory}

Emphasize the subject position of the learners, and promote the construction of learners' meaning. The prominent advantage of constructivism teaching design is that the learner is the subject of cognitive process and the active constructor of meaning, initiating students to explore actively and find, which requires the teaching tasks, teaching objectives, teaching evaluation and other aspects of the development process should be centered on the learner. First of all, we should 
improve students' enthusiasm and participation by designing a variety of real learning situations, using various learning resources (especially network resources, such as blog). At the same time, using task type, anchored, hairstyles of learning strategies to complete the self construction of knowledge.

For example, when teaching the class Современная молодежь - что это такое?, we can arrange the following questions before the introduction of the class: Чем характерна современная молодежьв 21-омвеке? Какое увлечение есть у молодежи? Чем отличается китайская молодежь от зарубе-жной, в частности, русской? Существует ли пере городка между молодежью и родителями? И какая? These questions can stimulate the interest of learners to learn the content of this lesson, so that they are in a kind of active learning situation. Then using the learned knowledge and experience, so that they answer how is the parents to complain about the young people. Finally, the students are divided into a number of discussion groups, each group with 4-5 stdents for the next class to discuss. To provide students with a few Russian information query site: www.rambler.ru, www.yandex.ru. This form allows each student to participate in the discussion of the topic of this lesson, and can also broaden the knowledge. At the end, students are required to try to use the new words and sentences in the text to consolidate the understanding of the text,

Attaching importance to the leading role of teachers, optimizing the construction of the learners' meaning. Constructivist instructional design emphasizes learner autonomy, but it does not mean to ignore the leading role of teachers in the constructivist learning theory. In multimedia teaching, the teacher's role should be changed from the knowledge infusion to a designer and organizer for students to acquire knowledge. Too much emphasis on learner autonomy and neglect of teachers' leading role may lead to the deviation of teaching objectives. In addition, the teacher's leading role is also reflected in the teaching effect and students' learning behavior evaluation. The innovation awareness and practical ability in the learning process should be given a positive attitude, so that they produce a sense of accomplishment and pride in the psychological.

Correctly handle the relationship between teaching methods and teaching purposes to promote the construction of the meaning of learners. Multimedia should be used as a teaching means to serve the purpose of teaching. It is not the only way to improve the quality of teaching and means, and it can not replace the replace the two-way communication between teachers and students in the teaching process, and the traditional teaching. The unique affinity, infectious force and teaching performance in the traditional teaching are beyond the reach of the multimedia means. The current multimedia teaching should focus on strengthening the construction of content, the appropriate combination of culture, history, geography, music, film and other national conditions, which can not only enrich the language learning of students, but also help to understand the Russian way of thinking. Therefore, the first principle of multimedia teaching design is to correctly grasp the status and role of multimedia technology in the teaching process, combine multimedia teaching with other teaching methods, to serve the purpose of teaching and create a better learning environment and language atmosphere.

\section{Conclusion}

The thought of constructivism is a profound educational revolution to the traditional teaching thought, so this article put forward a series of new and positive thoughts on learning and teaching based on it. The feedback of learners showed that multimedia teaching based on constructivism is 
popular. At the same time, with the development of the theory of constructivism, it can provide a strong theoretical basis for multimedia teaching, so it requires teachers to have a comprehensive ability of multimedia technology application and teaching design to guide students' autonomous learning and cultivate students' creative ability.

\section{Reference}

[1] Sun Mo: Problems and solutions in the construction of network multimedia teaching resources [J]. Chinese Audio Visual Education, 2011,07:88-91.

[2] He Nan. The problems and Countermeasures in multimedia teaching [J]. Heilongjiang Higher Education Research, 2006,01:127-129

.[3] Liu Juan. The use of multimedia teaching in Russian intensive reading class[J]. Russian literature and art, 2006,02:66-69.

[4] Sun Xianming, Fu Yanfeng. Problems and Countermeasures in Multimedia Teaching[J]. Educational Exploration, 2006,09:47-48.

[5] Gu Jiaqi. On the application of multimedia technology in Russian Teaching[J]. China Adult Education, 2012,03:140-141.

[6] Yu Zijie. Computer, multimedia technology and modern Russian teaching [J]. Chinese Russian Teaching, 2003,01:51-54. 